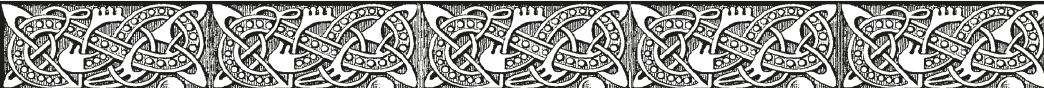

UDC 811.113.6+811.113.4+811.113.5

Yana V. Bocharova

Foreign Language Training Center of the National Research University of Information Technologies, Mechanics and Optics (ITMO University)

\title{
SCANDINAVIAN OR ENGLISH? THE LANGUAGES IN THE NORDIC CONTEXT
}

For citation: Bocharova Ya.V. Scandinavian or English? The languages in the Nordic context. Scandinavian Philology, 2018, vol. 16, issue 2, pp. 245-254. https:// doi.org/10.21638/11701/spbu21.2018.204

The article provides an overview of the use of the Scandinavian languages and English in the context of the Nordic Cooperation. The article provides an overview of the history and current status of using the Scandinavian languages and English is given, as well as the description of the current language situation. The study concentrates on the topic as viewed by researchers, performing artists, politicians, journalists and celebrities of the Nordic countries, which confirms the relevance of ongoing debate about pros and cons of using Scandinavian or English in academic, political and everyday contexts. The article examines, inter alia, the use of Scandinavian and English in the Nordic countries in close connection with the institutionalized political cooperation that took shape in the $20^{\text {th }}$ century. This cooperation is carried out mainly within the framework of the Nordic Council and the Nordic Council of Ministers. The institutionalization of cooperation resulted, among other things, in adoption of a number of strategic documents on language cooperation, such as the Declaration on a Nordic Language Policy and Nordic Language Convention. Since the article is an overview rather than an empirical study, and taking into account the relevance of the topic, further empirical research is proposed to identify trends in the attitudes of a wide range of respondents from the Nordic countries to the use of the Scandinavian and English languages in professional, cultural and everyday activities.

Keywords: Nordic countries, Scandinavian languages, English, Pan-Scandinavism, language community, Nordic Council, Nordic Council of Ministers, Declaration on a Nordic Language Policy, Nordic Language Convention.

This article is not an exhaustive research, rather an overview of the status of using Scandinavian and English languages in the Nordic 
context and an attempt to identify themes relevant for further research in the field.

While the term "Scandinavian" refers mostly to a North Germanic group of languages sharing the same origin, the term "Nordic" is widely used in order to describe languages spoken in a broader Nordic region, which also include a Finno-Ugric Finnish language and others.

According to Daniel Lindmark,"as a rule, the Nordic region (Norden in Scandinavian languages) refers to the nation-states of Denmark, Norway, Sweden, Finland and Iceland, and territories with varying degrees of political autonomy, including the Faroe Islands, Greenland, Sápmi and Åland" [Lindmark, 2015].

Cultural and historic proximity of the countries and autonomous territories of the Nordic region, rise of democracy and post-war economic growth in the $20^{\text {th }}$ century contributed to establishing an official political Nordic cooperation in a format of the Nordic Council in 1952 and the Nordic Council of Ministers in 1971. The countries of the region were ready to act together both regionally and internationally in order to achieve common goals.

The paper of the International Peace Institute "The Case of the Nordic Councils. Mapping multilateralism in transition No 1." quotes the following statement of Tom Schumacher: "Four factors were decisive for the emerging Nordic multilateral structures after World War II: first, the countries share common historical and cultural traditions, and their closely related languages enable transnational contacts on all societal levels; second, the division of labor within their joint institutions bears several advantages; third, the unequal power dynamics of several Nordic countries bordering major European military, economic, and cultural powers led to the solidification of a Nordic identity and a strengthening of Nordic cooperation; and finally, mutual support for a Nordic commitment to act independently in world politics" [Etzold, 2013].

The quoted statement and many other works point out that language identity and proximity were among decisive factors for solidification of the successful regional cooperation.

Evidently, the $20^{\text {th }}$ century was especially successful in terms of using Nordic cultural and language affinity as a basis of a broad Nordic cooperation. It is important to note, however, that the question of Nordic cultural and language unity has been addressed since at least mid-19 th $^{\text {th }}$ century. 
Thus, The Routledge Handbook of Scandinavian Politics provides an overview of how "Since 1840s, Scandinavian interstate relations were supplemented by a growing movement of cultural pan-Scandinavism inspired by similar movements on the European continent." In accordance with the Handbooks' authors, the Scandinavian approach was different from what we could witness in other European countries, because the language and culture were in focus, and not "the potential of the common state."

The web-based Projekt Runeberg describes a story of interaction between a famous Scandinavian linguist Jakob Lökke with his Scandinavian colleagues which, inter alia, resulted in his report „Beretning om det nordiske Retskrivningsmöte i Stockholm 25.-30. juli 1869” in relation to the Scandinavian spelling meeting in 1869.

The language being one of the cornerstones of this cooperation, use of the region's languages becomes an important focus area of strategic papers of the Nordic cooperation and is paid close attention to by researchers, public and the media.

The main strategic papers on the topic are the Nordic Language Convention (1981), signed on June 17, 1981 by plenipotentiary representatives of Sweden, Denmark, Finland, Iceland and Norway and effective from March, $1^{\text {st }} 1987$, and the Declaration on a Nordic Language Policy [Deklaration om nordisk sprogpolitik, 2007] signed and effective from November, $1^{\text {st }} 2006$.

The Nordic Language Convention ensures the right of the citizens of the Nordic countries to use their mother tongue when contacting public authorities in all signatory countries. The list of the languages contains Danish, Finnish, Icelandic, Norwegian and Swedish. The Convention even provides for significant public spending for the language services guaranteed to the citizens.

The Declaration on a Nordic Language Policy identifies general priority areas of effort while national governments bear responsibility for how the Declaration is followed up. The Declaration covers such themes as "teaching the Scandinavian languages both as neighboring and foreign languages; parallel language use of English and the main Nordic languages; the multilingual society and multilingual citizens; and the language used by official agencies (plain language use)".

Both documents highlight the importance of the region's languages and promote their use in all spheres of life as an integral part of societal development. 
The scope of political efforts on promoting the Nordic languages in the Nordic region seems to be second to none in Europe if not in the world.

It might therefore seem logical to assume that people in the Nordic countries do not face significant difficulties neither in free expression in their mother tongue all over the region nor in comprehension of spoken and written word in other neighboring countries.

First of all, it is important to note in this regard, that despite all efforts in order to promote equality of the regional languages and their broader use, there are three languages which are mostly referred to as languages whose speakers can understand each other without problems. These languages are Danish, Norwegian and Swedish.

Icelandic is considered too difficult to understand by many non-Icelandic speakers because of its well-preserved historical language pattern, while Finnish belongs to a Finno-Ugric group of languages which differs drastically from the Scandinavian group.

However, speakers of Icelandic and Finnish often demonstrate substantial knowledge of Danish and Swedish respectively because the Icelandic education system provides people with knowledge of a Scandinavian language, in most cases Danish, while Finnish school students attend compulsory Swedish classes because the second official language in Finland is Swedish.

Apart from the assumption about high level of understanding between the three major Scandinavian languages in the Nordic region, the Nordic countries are also famous for their good knowledge of English. As mentioned earlier, the Declaration on a Nordic Language Policy also encourages parallel use of English, especially in an academic context.

Good knowledge of English among Nordic citizens is often associated with its wide use in culture and education. It often surprises people from outside the Nordic region who try to explain this phenomenon. It is no coincidence that researchers, journalists and bloggers address this topic and express their views on how English became so popular and so well spoken in the Nordic countries.

Observations vary and include everything from traditional references to the Nordic people being willing to use English as an international language to high level of exposure to English inside the countries, like for example in Benny Lewis' "Here's why Scandinavians are so good at speaking English" [Lewis, 2017] and even a paradoxical conclusion that 
modern English itself is a Scandinavian language in contrast to the Old, or Anglo-Saxon, English. The latter theory was described in the University of Oslo's publication "UiO linguist makes sensational claim: English is a Scandinavian language" [Nickelsen, 2012].

Equipped with this background information about the status of Scandinavian and English in the Nordic societies, let us have an overview of some opinions which may support or argue against certain assumptions or patterns of language use.

In his "Educational History in the Nordic Region: Reflections from a Swedish Perspective" Daniel Lindmark notes that Scandinavian languages are welcome at some academic events and in some journals while recently "English has become more prominent". According to Lindmark, English is often chosen with the topic of internalization in mind, and also because it is a second language for many scholars, while Scandinavian can be a second or third language for e.g. Icelanders and Finns.

Like many other views, Lindmark's observation highlights perceived importance of English for internalization and indirectly refers to extra effort a Nordic person with a mother tongue different from the three major Scandinavian languages must undertake in order to enjoy the region's language unity and benefit from it.

An analysis of Nordic language policies prepared by a Norwegian Senter for internasjonalisering av utdanning [https://www.siu.no/] provides an overview of language policies in all five Nordic countries. In this review the authors Kate Sevón, Eyrún Sigurðardóttir and Dag Stenvoll point out that at a Nordic level the parallel use of English and Nordic languages is promoted and that future prospects are with multilingualism in the Nordic region. It is worth mentioning that, in accordance with the analysis, the most protective language policy is implemented by Iceland whose language does not belong to the major trio of the languages which are expected to facilitate understanding all over the Nordic region.

Per-Åke Lindblom in "Are the Nordic Languages threatened as Academic Languages?" (2009) addresses the challenges the Nordic languages face in academic use. The author claims that "the Nordic national languages are on their way to be replaced as theses languages by a new lingua franca, English". Lindblom uses some statistics in his paper to support his claim. 
Lindblom attributes the recent "expansion of English" to development of information technology. At the same time, he suggests that "the Nordic governments have not taken any measures against the expansion of English at academic levels, but on the contrary adopted a laissez faire policy".

Lindblom opposes the language parallelism promoted by the Declaration on a Nordic Language Policy and proposes some regulatory measures in order to preserve academic use of the Nordic languages and promote it. For example, he suggests the following with regard to Swedish language:

- ".....no course should be offered in English unless it is first offered in Swedish".

- “.....a Swedish speaking student shall be entitled to examination in her or his own language - with the exception of distinct language subjects. Foreign students shall be entitled to examination in English or other languages if adequate examiners are available."

- " ...... publication of scientific articles and theses shall not be disfavoured through quantitative measurements like impact factors".

- “.... a course books in Danish or Norwegian should always be preferred if they have the same scientific standard as the English ones".

Lindblom expresses his fears that with no measures undertaken the situation can resemble the one in Sub-Saharan Africa, "namely that no endogenous language is functioning as language of instruction within higher education or as scientific language".

Since Lindblom attributes this development to results of colonialism in Africa, he warns that a "self chosen colonialism" can play a central role in the similar process in the Nordic countries.

A broad overview of opinions of well-known Nordic citizens from different fields of activities is offered in the Nordic Council of Ministers' publication "Does the Nordic region speak with a FORKED tongue?" [Arvidsson, 2012], whose author, Karin Arvidsson, uses her background as a journalist and communicator in order to introduce debate and reflection over the language issue.

In the preface of the book an important question is raised "How does the way we handle the language issue affect Nordic collaboration?" 
The participants of the overview represent a wide spectrum of opinions and demonstrate different level of involvement into language-related activities. The selection brings together Her Majesty Queen Margrethe II of Denmark, popular TV people and politicians.

All interviewees of the publication have both personal and professional experience of using multiple languages in communication and they all happen to be educated people favouring use of the Nordic languages in communication both inside and between the Nordic countries.

Queen Margrethe II has personal experience of being raised in a multilingual family with her mother speaking English and Swedish as mother tongues. Despite her noble status, the Queen shares similar experience with many other Nordic citizens. She appears to be a supporter of learning each other's languages in the Nordic region and avoiding use of English in everyday communication between the Nordic countries.

In this context the Queen's attitude is presumably typical for both her generation of Nordic citizens, who attribute much importance to mutual understanding and unity, and her position as a monarch who is expected to promote her country's language and culture and contribute to maintaining friendship and peace among neighbours.

In the same publication a Norwegian journalist Fredrik Skavlan shares an interesting view on promoting Nordic cooperation: being a TV person, he uses a special mixed language in his shows, 'Swegian', which even annoys some people in Norway. He thinks that fight against English cannot bring any positive results. In his view, all Nordic languages should be modified in order to make them more understandable for people. Thus, he believes that "Danish pronunciation must be modified, Norwegian must be slowed down, and Swedish must be made clearer with a carefully chosen pan-Nordic vocabulary". His "Swegian", a mixture of Norwegian and Swedish, is a partial solution to this.

Even if Skavlans solution of forcibly modifying the languages may seem way too radical, it is a common practice among Scandinavian speakers to adjust what they say taking into account who their listeners are: for example, Danes tend to start pronouncing some words closer to what they look like in written, Norwegians try to use some Swedish words etc. Queen Margrethe also referred to a similar example in her part, explaining that she uses "femti and seksti instead of halvtreds and tres" when communicating with Norwegians. 
In the publication ex-president Ahtisaari represented a position of a politician who always puts law in the first place, and it was therefore clear to him that relevant provisions of the Finnish legislation should be followed and Swedish should be properly taught and used in Finland. Ahtisaari refused to admit any conflict between Finnish and Swedish in Finland and referred to media as a source of labeling the language situation as a conflict one.

It can be however supported by some observations that there are instances in Finland when Finnish speaking people avoid using Swedish and such avoidance can take different forms.

In general, this Nordic Council of Ministers' publication is a very good example of trying to address Nordic citizens and speakers of different Nordic languages and let them voice their views, as well as their considerations and their fears in relation to the languages they use every day in their private and professional lives.

Even if the publication refers merely to observations rather than empirical data, it is a very good basis for reflection which can result in a future full-fledged research where not only celebrities, but also people from all walks of life could be interviewed. Thus, extensive data could be collected for drawing convincing conclusions about how the Scandinavian languages and English behave in the context of real Nordic cooperation. Moreover, the publication reflects an emotional side of the topic of the language use in the Nordic countries: there are different opinions, but no one remains indifferent. It proves that the language is perceived as an important part of identity and society and there is space for further investigations of the issue.

Referring to a multitude of views and opinions expressed in different papers selected for this article as a source of the overview of the status of using Scandinavian and English languages in the Nordic context, and taking into consideration some personal observations of the author, who during many years contributed to the Nordic cooperation in her professional career, we believe that attitudes of people should be more thoroughly researched using representative groups of respondents. We believe that focus can be done on studying how people perceive their mother tongue in a broader Nordic context, how easy they find it to use one of the three "major" Scandinavian languages for communication and whether they see English as a threat or an opportunity. It is also of interest to study generational differences 
between the mentioned attitudes, as well as between attitudes between Nordic citizens with foreign background or without it.

\section{REFERENCES}

Arvidsson K. Available at: http://norden.diva-portal.org/smash/get/diva2:702612/ FULLTEXT01.pdf

Deklaration om nordisk sprogpolitik. Köpenhamn, 2007.

Etzold T. T. The Case of the Nordic Councils. Mapping multilateralism in transition, no. 1, 2013.

Lewis B. Available at: https://nordic.businessinsider.com/heres-why-scandinavians-are-so-good-at-speaking-english-2017-5/

Lindblom P.- $\AA$. Are the Nordic Languages threatened as Academic Languages? Brock-Utne, B. \& G. Gunnar (eds.). Language and Power. Tanzania, Mkuki na Nyota Publishers, 2009.

Lindmark D. Educational History in the Nordic Region: Reflections from a Swedish Perspective. Espacio, Tiempo y Educaciyn, 2015 2(2), pp.7-22. doi: http:// dx.doi.org/10.14516/ete.2015.002.002.001.

Nicklsen T. UiO linguist makes sensational claim: English is a Scandinavian language. 2012. Available at: https://www.apollon.uio.no/english/articles/2012/4-english-scandinavian.html (accessed: 08.06.2018).

Nordic Language Convention. Available at: http://back01.norden.clh.no:8090/ nordic/en/om-samarbejdet-1/nordic-agreements/treaties-and-agreements/ language/the-nordic-language-convention (accessed: 02.06.2018).

\section{Я.В. Бочарова}

Центр изучения иностранных языков Национального

исследовательского университета информационных технологий, механики и оптики (университет ИТМО)

\section{СКАНДИНАВСКИЙ ИЛИ АНГЛИЙСКИЙ?} ЯЗЫКИ В КОНТЕКСТЕ СЕВЕРНОГО СОТРУДНИЧЕСТВА

Для цитирования: Bocharova Ya. V. Scandinavian or English? The languages in the Nordic context // Скандинавская филология. 2018. Т. 16. Вып. 2. С. $245-$ 254. https://doi.org/10.21638/11701/spbu21.2018.204

Дается обзор использования скандинавского и английского языков в контексте сотрудничества северных стран. Предлагается исторический обзор положения скандинавских и английского языков в северных странах, особенностей их использования, а также описание текущей языковой ситуации. Отмечается пристальное внимание к вопросу со стороны деятелей науки, искусства, политиков, журналистов, а также знаменитостей стран Северной Европы, что подтверждает актуальность продолжающихся дебатов о плюсах и минусах использования скандинавских или английского языка в академическом, политическом и бытовом контекстах. Рассматриваются среди прочего вопросы использования 
скандинавских и английского языка в северных странах в тесной связи с институализированным политическим сотрудничеством, особенности которого формировались на протяжении ХХ в. Это сотрудничество осуществляется главным образом в рамках Северного совета и Совета министров северных стран. Институализация сотрудничества привела в том числе к принятию целого ряда стратегических документов по вопросам языкового сотрудничества, таких как Декларация языковой политики северных стран и Северная языковая конвенция. В связи с тем, что статья представляет собой обзор, а не эмпирическое исследование, и с учетом актуальности темы предлагается проведение дальнейших эмпирических исследований с целью выявления имеющихся трендов отношения широкого круга респондентов из северных стран к использованию скандинавских и английского языков в профессиональной, культурной и повседневной деятельности, в частности, исследование восприятия своего родного языка в широком скандинавском контексте, легкости или сложности использования одного из «основных» скандинавских языков в общении и оценки роли английского языка.

Ключевые слова: северные страны, скандинавские языки, английский язык, панскандинавизм, языковая общность, Северный совет, Совет министров северных стран, Декларация языковой политики северных стран, Северная языковая конвенция.

\author{
Yana Bocharova \\ National Research University \\ of Information Technologies, \\ Mechanics and Optics (ITMO University), \\ 49, Kronversky pr., St. Petersburg, Russia, 197101 \\ E- mail: yvbocharova@corp.ifmo.ru
}

Received: July 7, 2018

Accepted: August 30, 2018 